\title{
PENGARUH SERVICE QUALITY, WORD OF MOUTH, DAN BRAND AWARENESS TERHADAP KEPUTUSAN PEMBELIAN POLIS ASURANSI KENDARAAN DI JAKARTA
}

\author{
Hendra Wijaya \\ Program Studi Magister Manajemen Universitas Tarumanagara \\ hendra_wjy_ntzen@yahoo.com \\ Keni \\ Program Studi Magister Manajemen Universitas Tarumanagara \\ Masuk : 02-12-2020, revisi : 20-12-2020, diterima untuk diterbitkan : 21-12-2020
}

\begin{abstract}
The research aims to find out the influence of service quality, word of mouth, and brand awareness to purchase decision of vehicle insurance policy in Jakarta. The sampling method uses a non probability sampling technique in the form of convenience sampling with a total sample of 138 respondents and 115 valid data. Data collection method is done by distributing questionnaires online via google form. Data analysis technique using Partial Least Square - Structured Equation Modelling (PLS-SEM). The results of this research indicate that service quality, word of mouth, and brand awareness have an influence on purchase decision. Good service quality, positive word of mouth and also good brand awareness can increase purchase decision of vehicle insurance policy.
\end{abstract}

Keywords: Service Quality, Word of Mouth, Brand Awareness, Purchase Decision

Abstrak: Penelitian ini bertujuan untuk mengetahui pengaruh service quality, word of mouth, dan brand awareness terhadap keputusan pembelian polis asuransi di Jakarta. Metode pengambilan sampel menggunakan non probability sampling dalam bentuk teknik convenience sampling dengan total sampel sejumlah 138 responden dan 115 data yang valid. Pengumpulan data dilakukan dengan membagikan kuesioner secara online melalui google form. Teknik analisa data menggunakan Partial Least Square - Structured Equation Modelling (PLS-SEM). Hasil dari penelitian ini menunjukkan bahwa service quality, word of mouth, dan brand awareness mempunyai pengaruh terhadap keputusan pembelian. Service quality yang baik, word of mouth yang positif, dan juga brand awareness yang baik dapat meningkatkan keputusan pembelian polis asuransi kendaraan.

Kata kunci: Service Quality, Word of Mouth, Brand Awareness, Keputusan Pembelian

\section{PENDAHULUAN}

Berdasarkan Laporan Statistik \& Perkembangan Pasar Industri Asuransi Umum \& Reasuransi Tahun 2018 dari Asosiasi Asuransi Umum Indonesia (AAUI), pendapatan premi asuransi umum tahun 2018 bertumbuh sebesar 9,8\% dibanding tahun 2017.Produk yang berkontribusi terbesar kedua terhadap pendapatan premi asuransi umum yakni asuransi kendaraan sebesar 26,97\%. Menurut AAUI (2019), dari tahun 2017 sampai 2018, penjualan kendaraan roda dua meningkat sebesar $8,44 \%$, sedangkan penjualan kendaraan roda empat mengalami peningkatan sebesar $6,74 \%$. Oleh karena itu, asuransi kendaraan dapat menjadi peluang bisnis besar bagi perusahaan asuransi umum. Perusahaan perlu memfokuskan strategi yang tepat dalam mengembangkan pasar dan mendapatkan perhatian konsumen dalam penjualan produk asuransi kendaraan ke depannya. Keputusan pembelian polis asuransi kendaraan menjadi fokus utama perusahaan.

Terdapat beberapa variabel yang dapat menjelaskan keputusan pembelian. Menurut Firdausy dan Idawati (2017), keputusan pembelian dipengaruhi service quality dan price. 
Dalam penelitian Alfian dan Nilowardono (2019) bahwa social media marketing, word of mouth, dan brand awareness berpengaruh terhadap keputusan pembelian. Service quality merupakan salah satu faktor yang mempengaruhi keputusan pembelian. Pada penelitian Ali et al. (2018) diketahui service quality berpengaruh signifikan dan positif terhadap purchase decision. Selain itu, keputusan pembelian juga dipengaruhi variabel word of mouth. Menurut Ernawati et al. (2018) word of mouth memiliki pengaruh signifikan dan positif terhadap purchasing decision. Faktor lainnya yang mempengaruhi keputusan pembelian yakni brand awareness. Pada penelitian Ambolau et al. (2015) menunjukkan hasil bahwa brand awareness memiliki pengaruh signifikan dan positif terhadap keputusan pembelian.

Berdasarkan latar belakang di atas, penulis tertarik melakukan penelitian mengenai keterkaitan antara service quality, word of mouth, brand awareness dan keputusan pembelian. Tujuan penelitian ini adalah untuk menguji secara empiris pengaruh service quality, word of mouth dan brand awareness terhadap keputusan pembelian polis asuransi kendaraan di Jakarta. Hasil penelitian ini diharapkan dapat memberikan informasi yang berguna bagi perusahaan dalam menentukan variabel mana yang paling berpengaruh terhadap keputusan pembelian antara service quality, word of mouth, dan brand awareness sehingga perusahaan dapat mengembangkan pasar dan mendapatkan perhatian konsumen dalam penjualan produk asuransi kendaraannya, serta menentukan strategi bisnis yang tepat untuk meningkatkan penjualan produk asuransi kendaraannya.

\section{TINJAUAN PUSTAKA}

\section{Service Quality}

Menurut Palmer (2011:287) mengatakan bahwa " service quality is highly abstract construct, in contrast to good where technical aspect of quality predominate." Berdasarkan uraian di atas disimpulkan service quality merupakan penilaian konsumen terhadap harapan atas suatu layanan yang diterima dari perusahaan yang berfokus pada aspek kualitas dan kepuasan konsumen.

\section{Word of Mouth}

Walker (2001:63) mengemukakan word of mouth sebagai "informal person to person communication between a perceived non-commercial communicator and receiver regarding a brand, a product, an organization or a service." Dari definisi di atas disimpulkan word of mouth merupakan komunikasi tidak formal baik antar individu maupun berkelompok yang tidak ada unsur keuntungan dari pemberi informasi kepada penerima informasi tentang pemberian saran dan pengalaman yang dimiliki terhadap suatu merek, produk, jasa atau perusahaan sebagai informasi bagi dirinya.

\section{Brand Awareness}

Anwar et al. (2018:215) "the way of consumer to notice the brand and try to recall the brand by memorizing the brand from the certained product itself." Dari definisi di atas disimpulkan bahwa brand awareness merupakan suatu cara atau kemampuan konsumen mengidentifikasi dan memperhatikan suatu merek, mengenali dan mengingat merek produk tertentu dalam kondisi yang berbeda.

\section{Keputusan Pembelian}

Kotler dan Keller (2016: 198) mendefiniskan purchase decision sebagai "in the evaluation stage, the consumer forms preferences among the brands in the choice set and may also form an intention to buy the most preferred brand. Dari uraian di atas disimpulkan keputusan pembelian adalah suatu tahapan yang dilakukan konsumen dalam membeli suatu produk, dimana konsumen mengambil suatu tindakan atau membuat keputusan setelah memilih dan mengevaluasi beberapa pilihan untuk menyelesaikan permasalahannya. 


\section{Kaitan Antar Variabel}

\section{Pengaruh Service Quality Terhadap Keputusan Pembelian}

Penelitian yang dilakukan Oscar dan Keni (2019) menyatakan service quality berpengaruh terhadap keputusan pembelian konsumen. Service quality harus diperhatikan dikarenakan suatu persepsi yang dibentuk konsumen dari pengalaman yang diperoleh saat melakukan pembelian suatu produk. Hasil penelitan serupa ditemukan Firdausy dan Idawati (2017) menyatakan service quality dapat mempengaruhi keputusan konsumen dalam pembelian. Semakin baik service quality yang diberikan perusahaan, maka semakin besar kesempatan konsumen memutuskan membeli produknya. Berdasarkan pernyataan diatas, maka hipotesis penelitian adalah sebagai berikut:

H1 : Service quality memiliki pengaruh positif terhadap keputusan pembelian polis asuransi kendaraan di Jakarta

\section{Pengaruh Word of Mouth Terhadap Keputusan Pembelian}

Dalam penelitian yang dilakukan Ernawati, et al. (2018) menunjukkan word of mouth mempunyai pengaruh signifikan dan positif terhadap purchase decision. Word of mouth yang positif dapat meningkatkan keinginan konsumen dalam memutuskan pembelian. Berdasarkan pernyataan diatas, maka hipotesis penelitian adalah sebagai berikut:

$\mathrm{H} 2$ : Word of mouth memiliki pengaruh positif terhadap keputusan pembelian polis asuransi kendaraan di Jakarta

\section{Pengaruh Brand Awareness Terhadap Keputusan Pembelian}

Menurut penelitian Ambolau, et al. (2015) menunjukkan purchase decision suatu produk dipengaruhi secara signifikan dan positif oleh brand awareness. Sebelum memutuskan membeli suatu produk, konsumen biasanya menyadari merek produk terlebih dahulu. Studi lainya, Alfian dan Nilowardono (2019) menemukan brand awareness memiliki pengaruh signifikan dan positif terhadap keputusan pembelian. Konsumen akan membeli produk yang mereknya sudah ia ketahui dan merasa aman menggunakan produk tersebut. Berdasarkan pernyataan diatas, maka hipotesis penelitian adalah sebagai berikut:

H3 : Brand Awareness memiliki pengaruh positif terhadap keputusan pembelian polis asuransi kendaraan di Jakarta

Berdasarkan uraian kaitan antar variabel di atas, maka model penelitian yang digunakan dapat digambarkan sebagai berikut:

\section{Gambar 1 Model Penelitian}

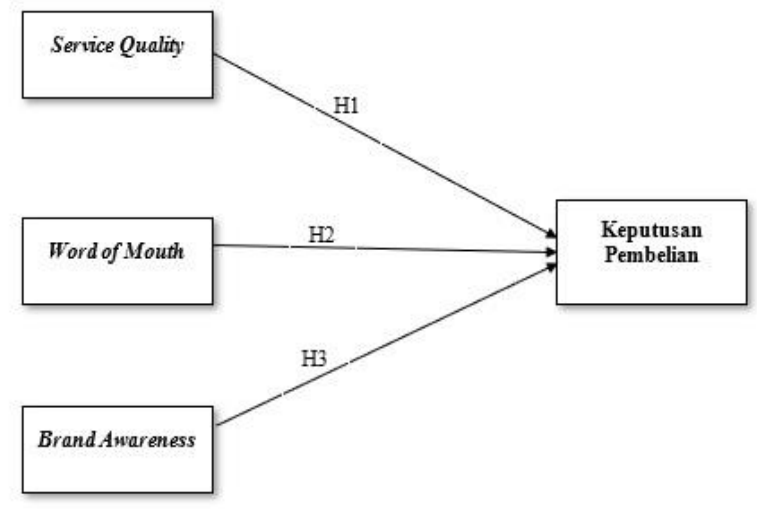

\section{METODOLOGI PENELITIAN}

Jenis penelitian ini merupakan penelitian deskriptif cross-sectional, periodenya dimulai dari Desember 2019 sampai November 2020. Pengumpulan data diperoleh dari data primer menggunakan penyebaran kuesioner online lewat Google Form. Sampel penelitian ini yakni pelanggan yang sedang membeli atau memperpanjang asuransi kendaraan wilayah Jakarta, 
menggunakan non probability sampling dengan teknik convenience sampling. Sampel pada penelitian ini sejumlah 115 responden dari 138 kuesioner yang berhasil terkumpul.

Hasil pengolahan data kuesioner menunjukkan bahwa karakteristik mayoritas responden adalah wanita $(52,2 \%)$, rentang usia $35-49$ tahun $(45,2 \%)$ yang pendidikan terakhirnya lulusan S1 $(77,4 \%)$. Sebagian besar responden bekerja sebagai pegawai swasta/negeri $(64,3 \%)$, mempunyai pengeluaran rata-rata per bulan di atas Rp.10.000.000,- $(49,6 \%)$, berdomisili di Jakarta Barat $(31,3 \%)$ dan merupakan nasabah asuransi kendaraan yang sudah lebih dari 3 tahun $(50,4 \%)$.

Di dalam penelitian ini, service quality, word of mouth dan brand awareness merupakan independent variable dan keputusan pembelian merupakan dependent variable. Pengukuran indikator dari variabel ini menggunakan 5 (lima) poin skala Likert, dengan nilai 5 artinya "sangat setuju" dan nilai 1 artinya "sangat tidak setuju".

\section{Tabel 1}

\begin{tabular}{ccc}
\multicolumn{2}{c}{ Indikator Pengukuran Variabel } \\
Variabel & Item & Sumber \\
\hline Service Quality & 15 item & Parasuraman et al. $(1988)$ \\
\hline Word of Mouth & 6 item & Sari dan Astuti (2012) \\
\hline Brand Awareness & 6 item & Nigam dan Kaushik (2011) \\
\hline Keputusan Pembelian & 6 item & Firdausy dan Idawati (2017)
\end{tabular}

Teknik analisis data menggunakan Partial Least Square-Structured Equation Modelling (PLS-SEM) melalui software Smart PLS 3.3.2. Dari hasil analisis outer model, ditemukan 5 indikator yang nilai loading factor tidak memenuhi syarat > 0,70 (Hair et al., 2014) sehingga indikator-indikator tersebut tidak digunakan dalam model penelitian. Setelah 5 indikator tersebut dikeluarkan, semua indikator didalam model penelitian bersifat valid dan reliabel sehingga dapat disimpulkan variabel-variabel dalam penelitian ini dapat dipercaya dan diandalkan. Hasil analisis validitas konvergen, yaitu nilai AVE $\geq 0,50$ dan loading factor $>$ 0,70 (Hair et al., 2014) juga validitas diskriminan, yaitu kriteria Fornell- Larcker dan nilai cross loading (Hair et al., 2014) serta nilai composite realiability > 0,7 dan Cronbach Alpha > 0,7 (Ghozali dan Latan (2015). Hal ini menunjukkan bahwa semua indikator penelitian telah memenuhi nilai syarat minimum dari metode pengukuran yang digunakan.

ANALISA \& PEMBAHASAN

\section{Tabel 2}

\section{Hasil Analisis Path Coefficient}

\begin{tabular}{ccccc} 
Hipotesis & Variabel & Path Coefficient & t-statistic & p-value \\
\hline $\mathrm{H}_{1}$ & Service Quality $\rightarrow$ Keputusan Pembelian & 0,215 & 2,195 & 0,029 \\
\hline $\mathrm{H}_{2}$ & Word of Mouth $\rightarrow$ Keputusan Pembelian & 0,521 & 6,526 & 0,000 \\
\hline $\mathrm{H}_{3}$ & Brand Awareness $\rightarrow$ Keputusan Pembelian & 0,212 & 2,468 & 0,014
\end{tabular}

Berdasarkan hasil pengujian hipotesis dengan path-coefficient dan bootstrapping pada tabel di atas dapat disimpulkan bahwa service quality, word of mouth, dan brand awareness mempunyai pengaruh positif terhadap keputusan pembelian. Hipotesis pertama ini didukung hasil penelitian yang dilakukan oleh Oscar dan Keni (2019) dan Firdausy dan Idawati (2017) yang mengemukakan bahwa service quality berpengaruh terhadap keputusan konsumen dalam pembelian produk. Dalam hal ini, pelayanan klaim yang dapat dipertanggungjawabkan dan tepat sesuai kesepakatan perjanjian polis. Karyawan yang memiliki pengetahuan baik dan sopan, melayani pelanggan dengan cepat, care serta bersedia membantu serta memberikan perhatian khusus kepada pelanggan akan meningkatkan kepuasan konsumen sehingga menciptakan sevice quality yang baik bagi perusahaan. Hipotesis kedua sama dengan hasil penelitian dari Ernawati, et al. (2018) dan Alfian dan Nilowardono (2019) yang menyampaikan word of mouth mempunyai pengaruh signifikan dan positif terhadap keputusan pembelian. Pengalaman konsumen yang puas terhadap layanan dapat menciptakan informasi positif sehingga akan mempengaruhi dan mengajak orang di sekitarnya untuk menggunakan produk 
asuransi kendaraan. Rekomendasi positif konsumen menjadi pertimbangan konsumen dalam mencoba dan memutuskan membeli polis asuransi kendaraan. Hipotesis terakhir penelitian ini sama dengan yang dikemukakan Ambolau, et al. (2015) dan Alfian dan Nilowardono (2019) menunjukkan brand awareness memiliki pengaruh signifikan dan positif terhadap keputusan pembelian. Ketika membeli polis asuransi kendaraan, merek yang pertama kali diingat dan logo merek yang dapat cepat dikenali baik dibanding dengan merek kompetitor. Merek yang telah dikenal baik ini, dapat diartikan bahwa perusahaan telah memiliki brand awareness yang kuat. Semakin kuat brand awareness dari merek, akan meningkatkan keputusan pembelian polis asuransi kendaraan.

\section{HASIL \& KESIMPULAN Kesimpulan}

Hasil penelitian ini menununjukkan service quality, word of mouth, dan brand awareness mempunyai pengaruh positif signifikan terhadap keputusan pembelian polis asuransi kendaraan. Hasil penelitian menunjukkan bahwa word of mouth merupakan prediktor terbesar terhadap perubahan naik turunnya keputusan pembelian.

\section{Implikasi Manajerial}

Pertama, hasil penelitian menunjukkan bahwa mayoritas responden menganggap service quality dari sebuah produk menunjukkan pengaruh positif signifikan terhadap keputusan konsumen dalam membeli produk. Perusahaan dapat terus meningkatkan pelayanan klaim, dengan membuat standard operating procedure beserta service level agreement, menambah rekanan bengkel authorized, dan melakukan review kepuasan konsumen rutin terhadap performance bengkel rekanan. Perusahaan juga perlu melakukan training dan seminar berkala kepada karyawannya mengenai product knowledge, pentingnya service excellent dan communication skill serta memberikan apresiasi reward dan bonus bagi marketing dan klaim officer yang telah memberikan service excellent bagi customernya. Kedua, hasil penelitian ini mengemukakan bahwa mayoritas responden menganggap word of mouth ini sangat penting dalam industri asuransi kerugian, khususnya asuransi kendaraan, ditunjukkan adanya pengaruh positif terhadap keputusan pembelian. Saran peneliti adalah untuk fokus dalam menciptakan word of mouth positif melalui pelanggannya, bisa meminta referensi dan rekomendasi dari pelanggan yang puas atas pelayanan dan strategi marketing referral dari nasabah existing yang mempunyai pengalaman baik. Selain itu, perusahaan perlu juga mengembangkan dan mengontrol website dan social media perusahaan, berisi informasi terkini perusahaan dan menyediakan sarana Imemberikan testimoni positif pelanggan sehingga konsumen semakin yakin memutuskan pembelian produk asuransi kendaraan. Terakhir, hasil penelitian ini menunjukkan adanya pengaruh positif antara brand awareness dan keputusan pembelian. Peneliti menyarankan perusahaan tetap mempertahankan top of mind-nya di masyarakat melalui motto perusahaan yang terintegrasi dengan integrated marketing communication sesuai visi dan misi perusahaan, melalui kegiatan public relation dan corporate social responsibility secara rutin, iklan, dan inovasi produk terus-menerus sesuai kebutuhan market sehingga dapat meningkatkan awareness terhadap merek.

\section{Saran untuk penelitian selanjutnya}

Peneliti menyarankan penelitian selanjutnya meneliti dengan karakteristik responden yang berbeda dengan penelitian ini. Penelitian selanjutnya dapat menggunakan subjek dan variabel yang sama atau berbeda juga mengkombinasikan variabel lainnya pada penelitian ini. Jumlah sampel yang lebih besar diharapkan meningkatkan hasil uji lebih mendekati akurat.

\section{DAFTAR PUSTAKA}

Alfian, N. \& Nilowardono, S. (2019). The Influence of Social Media Marketing Instagram, Word of Mouth and Brand Awareness of Purchase Decisions on Artenis Tour and Travel. International Journal of Entrepreneurship and Business Development, 2, 218-226. 
Ambolau, M. A. P., Kusumawati, A., \& Mawardi, M. K. (2015). The Influence Of Brand Awareness and Brand Image on Purchase Decision (Study on Aqua Consumers in Administrative Science Faculty Brawijaya University Class of 2013). Jurnal Administrasi Bisnis, 2, 1-8.

Anwar, S.K., Kusumawati, A., \& Sanawiri, B. (2018). Influence of Brand Awareness and Product Attribute Toward Purchase Decision (Study on the Undergraduate Students of Administrative Science Faculty of 2014 Batch as Samsung Smartphone Consumers and Users Customer). Jurnal Administrasi Bisnis, 5 (1), 214-221.

Asosiasi Asuransi Umum. (2019). Laporan Statistik \& Perkembangan Pasar Industri Asuransi Umum \& Reasuransi Tahun 2018.

Ernawati, Sri, Muhajirin, \& Ismunandar. (2018). The Effect of Word of Mouth (WOM) on Purchasing Decision of Region Exclusive Fabric of West Nusa Tenggara Province (Case Study on Sasambo Fabric in Bima City). Jurnal Terapan Manajemen dan Bisnis, 4, $115-$ 119.

Firdausy, M. C., Idawati, R. (2017). Effect of Service Quality, Price and Promotion on Customers' Purchase Decision of Traveloka Online Airline Tickets in Jakarta, Indonesia. International Journal of Management Science and Business Administration, 3 (2), 4249.

Ghozali, I. \& Latan, H. (2015). Partial Least Square Konsep, Teknik dan Aplikasi Menggunakan Program SmartPLS 3.0 untuk Penelitian Empiris ( $2^{\text {nd }}$ ed.). Semarang : Badan Penerbit Universitas Diponegoro.

Hair, J. F., Hult, G.T.M., Ringle, Christian M., \& Sarstedt, M. (2014). A Primer on Partial Least Squares Structural Equation Modeling (PLS-SEM). USA : SAGE Publications Inc.

Kotler, P. \& Keller, K.L. (2016). Marketing Management (15 ${ }^{\text {th }}$ ed.). USA: Pearson Education Inc.

Nigam, A. \& Kaushik, R. (2011). Impact of Brand Equity on Customer Purchase Decisions: An Empirical Investigation with Special Reference to Hatchback Car Owners in Central Haryana. International Journal of Computational Engineering \& Management, 12, 121 128.

Oscar, Y. \& Keni. (2019). Pengaruh Brand Image, Persepsi Harga, Dan Service Quality Terhadap Keputusan Pembelian Konsumen. Jurnal Muara Ilmu Ekonomi dan Bisnis, 3, 20-28.

Palmer, A. (2011). Principles of Service Marketing (6 ${ }^{\text {th }}$ ed.). New york : McGraw-Hill Inc.

Parasuraman, A., Berry, L.L., \& Zeithaml, V.A. (1988). SERVQUAL: A Multiple-Item Scale for Measuring Consumer Perceptions of Service Quality. Journal of Retailing, 64, 1240.

Sari, Ratna D.K., Astuti, Sri R.T. (2012). Analisi Pengaruh Kualitas Produk, Persepsi Harga, dan Word of Mouth Communication terhadap Keputusan Pembelian Mebel pada CV. Mega Jaya Mebel Semarang, Diponegoro Journal of Management, 1, 1-13.

Walker, L.J.H. (2001). The Measurement of Word of Mouth Communication and an Investigation of Service Quality and Customer Commitment as Potential Antecedents. Journal of Service Research, 4(1), 60-75. 